\title{
PROFESSIONAL ORIENTATION OF MATHEMATICAL TRAINING OF THE BACHELOR IN NAVIGATION
}

\author{
Olena Cherkas ${ }^{1}$, Natalia Bykovets ${ }^{2}$, Mariia Chumachenko ${ }^{3}$,
}

1 Candidate of Physical and Mathematical Sciences Associate Professor of the Department of General Sciences of the Danube Institute of the National University "Odessa Maritime Academy" http://orcid.org/0000-0001-5539-3946

e-mail: cherkas.elena55@gmail.com

2 Candidate of Technical Sciences Head of the Department of General Sciences of the Danube Institute of the National University "Odessa Maritime Academy" http://orcid.org/0000-0002-6365-4701. Researcher: B-6193-2019 e-mail: bnp.di2017@gmail.com

3 Senior Lecturer of the Department of General Sciences of the Danube Institute of the National University "Odessa Maritime Academy"

http://orcid.org/0000-0002-1618-6175

e-mail:m.n.chumachenko@gmail.com

\begin{abstract}
The article discusses the competences in Mathematics of a prospective Bachelor in Navigation. Mathematical competence is defined as a function of competencies: general and subject-specific. It's manifested that mathematics acts as a fundamental discipline for the further mastering of specialized disciplines. The article suggests the competence approach to mathematical education based on the analysis of professional requirements as the methodology of the research. These requirements determine the priority of the competencies required for professional activities of a bachelor in navigation.

The article states the principal provisions of the competence approach in terms of the Tuning methodology; classification of the general and subject-specific competencies of the Bachelor in navigation required for successful professional activities; analysis of the structure and content of the mathematical training of the prospective Bachelor in Navigation in some Higher Maritime Educational Institutions in Ukraine and Europe. In accordance with the IMO (International Maritime Organization, 2014) standards, the requirements for teaching mathematics to the undergraduate students are presented; the relationships between the tasks of vocational orientation and the corresponding blocks of Higher Mathematics discipline are investigated. The analysis of the determined tasks as well as cooperation with the lecturers of the specialized disciplines allows to formulate the content of the Higher Mathematics course paying sufficient attention to those sections of mathematics that are necessary for vocational training of the navigators; examples of types of the mathematical competence formation control are given; the contribution of the mathematical competence to the integral, general and special competencies indicated in the profile of a higher educational institution is manifested; the significance of Mathematics in programme training outcomes is stated.

The article suggests that the tools and approaches of the Tuning project provide effective monitoring, evaluation and improvement of the curriculum for achieving the object and making pertinent changes in the relevant subject areas.
\end{abstract}

Keywords: mathematical competence, Bachelor in Navigation, IMO standards, programme training outcomes, Mathematics.

Introduction. The urgency of the issue of mathematical competences development of the prospective Bachelor in Navigation is determined by the changes of the educational paradigm in higher education, rapid updating of information technologies, and integration of Ukrainian higher education into the common European educational environment. Development of the skilled specialist's vocational competence, first of all, is performed in the educational process of the Higher Education 
Institutions (HEI). Contemporary society makes ever increasing demands on the HEI in responding to needs in training the competitive specialists with the established competencies in various fields, including mathematical ones.

We consider mathematical competence to be the system of mastered mathematical knowledge and methods, and also the ability to apply them for solving professional tasks. The acquired knowledge of the higher mathematics' theoretical foundation and the proficiency in mathematical tools are the basis for mastering the disciplines of the vocational cycle.

Materials. Issues concerning the modernization of professional education based on a competence approach have been developed in the researches of foreign (N. Talizina, A. Khutorsky, N. Khodireva, L. Ustinova and others) and Ukrainian (M.Pratzovytyi, V.Shvets, V.Klochko, M. Shkil and others) scholars. For example, A. Khutorsky (A. Khutorsky, 2005) considers competence as the form of a pre-formulated requirement for educational training of the subject expressed by a set of knowledge, skills and models of activities necessary for the effective performance in a particular field. Under the professional mathematical competence Y. Stelmakh (Stelmakh, 2011, p.2). understands the integrative ability of the individual, which provides preparedness for applying mathematical tools independently in accordance with the tasks of vocational activities.

The aim of the paper. The objective of the study is to determine the content of the Bachelor in navigation holders' mathematical competence.

Methods. For this purpose, a number of methods have been applied, namely theoretical ones (studying the normative documents and training programmes in the Higher Education Institutions (HEI) of maritime profile, in particular, the National University "Odessa Maritime Academy" and some maritime higher education institutions of European countries) and practical (results of foreign internships as well as teaching experience).

Results and discussions. Developing the Higher Mathematics (HM) course content we followed the Tuning methodology (translated from English: the action or process of tuning something; setting, regulation, harmonization) (TUNING Educational Structures in Europe, 1999) in our research. This methodology investigates the competence approach, which, in turn, is based on the analysis of professional requirements that determine the priority of the competencies required in a particular area of professional activities. The Tuning project is aimed at bringing educational structures closer to the countries participating in the Bologna process, including Ukraine.

Curriculum development aimed at educational outcomes facilitates a significant flexibility of the process. Unlike the conventional one, the module system has a number of advantages: it makes the training process more standardized and transparent relating to a certain specialty; provides the opportunity to obtain comparative results in different periods of study; assures student mobility through simplified students transfer system based on learning outcomes to move from one IHE to another, and with the ability to participate in Erasmus + Student Exchange Programs (2014).

The concept of outcomes compatibility preserves the autonomy of educational institutions and ensures diversity through the modules composing.

Under the Tuning project, the European Credit Transfer System (ECTS) (Rashkevich, 2014, pp. 4663) has been developed: credits reflect the volume, and the learning outcomes manifest the content of this process. The number of credits determines the time required for achieving learning outcomes by an average student in accordance with the specifics of the educational institution and the training tradition.

The Tuning project comprises educational outcomes, which are expected indicators of student's abilities and skills determining what the student must know, understand, and be able to perform having completed the training process. The suggested results are formed by teachers. The student's acquired training outcomes are defined within certain competencies.

We define the following general competences to be acquired by a student while studying mathematical disciplines (TUNING Educational Structures in Europe, 1999): the ability to analyze and synthesize; basic knowledge in the main field of study, as well as in related fields; ability to solve problems and tasks; ability to apply knowledge in practice; perception of ideas from other subject areas; elementary computer skills; quantitative thinking; obtaining qualitative information from quantitative data; research skills; ability to adapt to new situations; creativity.

Revising the general list of subject-specific competencies (TUNING Educational Structures in Europe, 1999), we have identified exactly those which the prospective Bachelors in navigation should acquire while learning mathematical disciplines. They are: profound knowledge of the main sections of elementary mathematics (school course); the ability to solve mathematical problems and tasks, similar to previously studied but of a higher complexity level; the ability to transcode into the mathematical system the simplest problems posed in the formulation of other subject fields and to take advantage of this reformulation for further solution; the ability to construct mathematical models for the description and further study of non-mathematical processes; the ability to correctly interpret received mathematical 
results in non-mathematical contexts; knowledge of software and its application for mathematical problems solving and obtaining additional information; ability to read and analyze educational and scientific mathematical literature, including published in a foreign language; the ability to represent and prove mathematical statements, to identify, to state clearly and solve problems that are understandable to the professional audience in written and oral form.

Having applied theoretical and practical methods, we can state the obtained research findings.

I. Having got the access to the websites of certain maritime institutions of higher education in Europe, an analysis of the teaching mathematical disciplines have been carried out in accordance with the indicated parameters: in which semester (or semesters) are these disciplines studied; what amount of credits is provided for mastering the discipline; as well as the content of the defined disciplines' study programmes.

Table 1 summarizes the outcomes of the study.

The given results prove it possible to draw the following conclusions: from 9 to 13 credits are assigned for mastering the required knowledge and skills in mathematics for the Bachelors in Navigation; the content of the curriculum in mathematics is determined by the IMO and national standards.

Taking into account the requirements of the IMO for training the prospective Bachelor in navigation contained in sections A-II / 1 and A-II / 2 of the STCW (Standards of Training, Certification and Watchkeeping for Seafarers) for every officer in charge of a navigational watch or master serving on seagoing ship of 500 gross tonnage or more, particularly concerning the problem of mastering knowledge and skills in "Mathematics", there appeared to be the need to reflect the structure and content of mathematics in compliance with the IMO standards (IMO 7.03 module course Appendix 1. Mathematics (2014). In this structure, sections of mathematics are definitely determined with the recommended amount of hours per lectures and practical training. Thus, we present the summary table as follows:

1) Algebra: lectures -3 , practice -3 ;

2) Graphs: lectures -3 , practice -3 ;

3) Proportions, interpolation: lectures -3 , practice -5

4) Geometry: lectures -4 , practice -6 ;

5) Trigonometry: lectures -2 , practice -4 ;

6) Measurements: lectures -1 , practice -5 ;

7) Spherical triangles: lectures -5 , practice -11 ;

8) Vectors: lectures -2 , practice -4 ;

9) Circle, ellipse, hyperbole: lectures -2 , practice -2 ;

10) Statistics: lectures -3 , practice -1 .

Totally, for the course -72 hours, lectures -28 ; practical classes -44 .

It should be noted that the content and the number of hours assigned for the course remain unchanged, but the number of hours assigned for lectures and practical classes may vary at the teacher's discretion. Appendix 1 Mathematics provides a list of knowledge and skills of the Bachelor in navigation for each sections of mathematics in the IMO 7.03 modeling course given above.

We suggest exploring more closely the mentionedabove list on the example of the topic "Spherical Triangles". 16 hours are assigned for learning this issue. According to the requirements, the bachelor should know (we give only a small number of questions): definition of a large circle, small circle, pole; definition of a spherical triangle as a figure on the surface of a sphere formed by three intersecting pairs of arcs of large circles; know that the sum of the angles of the spherical triangle is greater than 180 but less than 540; for the given two elements of a rectangular spherical triangle, find other elements applying Neper's rules.

III. In the National University "Odessa Maritime Academy" Higher Mathematics discipline, which is

Table 1

\section{Results of the study of teaching mathematical disciplines in certain maritime universities of Europe}

\begin{tabular}{|c|c|c|c|}
\hline HEI & Discipline & Semester & Credits \\
\hline \multirow{2}{*}{$\begin{array}{l}\text { Lithuania. Lithuanian } \\
\text { Maritime Academy (LMA) / } \\
\text { Lietuvos aukstosios jureivystes } \\
\text { mokyklos (LAJM) (2019) }\end{array}$} & Applied mathematics & 1 & 4 \\
\hline & Mathematics for navigation & 2 & 5 \\
\hline \multirow[t]{2}{*}{ Germany. Jade-Hochschule (2019) } & Mathematics & 1 & 5 \\
\hline & Statistics & 3 & 5 \\
\hline \multirow{2}{*}{$\begin{array}{l}\text { Germany. Hochschule Flensburgof } \\
\text { Applied Sciences (2019) }\end{array}$} & Mathematics & 2 & 5 \\
\hline & Mathematics & 3 & 5 \\
\hline Ukraine. Nationa University & Higher Mathematics & 1 & 5 \\
\hline \multirow[t]{2}{*}{ "Odessa Maritime Academy" (2019) } & Higher Mathematics & 2 & 5 \\
\hline & Mathematics for navigation & 3 & 3 \\
\hline
\end{tabular}


taught in the first and second semesters, covers 10 credits (300 hours). These hours are distributed as follows: for a lecture course -74 , for practical classes -66 , for independent work -160 . The indicated discipline is the basis for the other disciplines being studied at the next courses. The main topics taught during the study are: linear algebra; vector algebra; analytic geometry; differential calculus of functions of one and many variables; integral number of a single variable function; ordinary differential equations and their systems; numerical and functional rows; operational calculus; Probability theory and mathematical statistics; spherical trigonometry.

IV. In the course of fundamental training of the Bachelor in navigation, the discipline "Mathematical Principles of Navigation" is taught. Knowledge gained during the study of "Higher Mathematics" and "Navigation and Loya" is the prerequisite for the discipline learning. The discipline programme covers mathematical foundations which are considered

Table 2

\section{The relationship of disciplines with Higher Mathematics course}

\begin{tabular}{|c|c|c|}
\hline Task & Discipline & Block in "Higher mathematics" course \\
\hline Calculation of the arc of a large circle (ALC) & $\begin{array}{l}\text { Fundamental } \\
\text { Mathematics } \\
\text { for navigation }\end{array}$ & Spherical trigonometry \\
\hline $\begin{array}{l}\text { Determination of the ship's position with two } \\
\text { positioning lines }\end{array}$ & $\begin{array}{l}\text { Fundamental } \\
\text { Mathematics } \\
\text { for navigation }\end{array}$ & $\begin{array}{l}\text { Algebra, trigonometry, differential calculus, } \\
\text { construction of geometric figures }\end{array}$ \\
\hline $\begin{array}{l}\text { Processing of measurements of navigation } \\
\text { parameters }\end{array}$ & $\begin{array}{l}\text { Fundamental } \\
\text { Mathematics } \\
\text { for navigation }\end{array}$ & Probability theory and mathematical statistics \\
\hline $\begin{array}{l}\text { Assesment of the accuracy of observation } \\
\text { by an ellipse error }\end{array}$ & $\begin{array}{l}\text { Fundamental } \\
\text { Mathematics } \\
\text { for navigation }\end{array}$ & $\begin{array}{l}\text { Probability theory and mathematical statistics, } \\
\text { construction of geometric figures }\end{array}$ \\
\hline Navigation information errors & $\begin{array}{l}\text { Fundamental } \\
\text { Mathematics } \\
\text { for navigation }\end{array}$ & Probability theory and mathematical statistics \\
\hline Measures to improve the safety of navigation & $\begin{array}{l}\text { Fundamental } \\
\text { Mathematics } \\
\text { for navigation }\end{array}$ & Probability theory and mathematical statistics \\
\hline Parallax light triangle & Nautical Astronomy & Spherical trigonometry \\
\hline Calculation of buoyancy and stability & $\begin{array}{l}\text { Theory of vessel } \\
\text { structure }\end{array}$ & $\begin{array}{l}\text { Defined integral. Integral calculus for area } \\
\text { determination (approximate quadrature } \\
\text { formulas) }\end{array}$ \\
\hline Calculation of the stability of the vessel & $\begin{array}{l}\text { Theory of vessel } \\
\text { structure }\end{array}$ & $\begin{array}{l}\text { Analytical geometry. The notion of curvature } \\
\text { and evolution, the connection between the } \\
\text { coordinates of evolution points and evolvents }\end{array}$ \\
\hline Calculation of the roll of the vessel & $\begin{array}{l}\text { Theory of vessel } \\
\text { structure } \\
\text { coefficients }\end{array}$ & $\begin{array}{l}\text { Differential equations. Integration of aggregate } \\
\text { linear differential equations with constant }\end{array}$ \\
\hline Seaworthiness/navigability characteristics & $\begin{array}{l}\text { Theory of vessel } \\
\text { structure }\end{array}$ & Vector algebra. Actions with vectors \\
\hline Formation and expansion of forces & Theoretical mechanics & $\begin{array}{l}\text { Elements of vector algebra. } \\
\text { Properties of triangles }\end{array}$ \\
\hline $\begin{array}{l}\text { Finding the moment of force relative } \\
\text { to the point }\end{array}$ & Theoretical mechanics & Elements of analytic geometry \\
\hline $\begin{array}{l}\text { The solution of the first and second } \\
\text { dynamics tasks }\end{array}$ & Theoretical mechanics & $\begin{array}{l}\text { Fundamentals of differential calculus. } \\
\text { Properties of defined integrals }\end{array}$ \\
\hline $\begin{array}{l}\text { Studies of free, fading and forced } \\
\text { board fluctuations }\end{array}$ & Theoretical mechanics & Differential equations \\
\hline $\begin{array}{l}\text { The movement of the vessel in the area of the } \\
\text { direct current (direct and inverse task) }\end{array}$ & Theoretical mechanics & Vector algebra. Properties of triangles \\
\hline Divergence of vessels (direct and inverse task) & Theoretical mechanics & Vector algebra. Properties of triangles \\
\hline
\end{tabular}


important for the knowledge acquired in accordance with the various competences of Section A-II / 1 and Section A-II / 2 of the STCW Code for an officer in charge of a navigational watch or master serving on seagoing ships of 500 gross tonnage or more.

The study of the discipline "Mathematical Principles of Navigation" provides the Bachelor in Navigation with the following competencies: the ability to plan and navigate the voyage (SC2); the ability to navigate in any conditions using appropriate methods to obtain accurate positioning and optimally use all available navigational data for navigation (SC3).

The programme learning outcomes are: ability to solve general mathematical problems for performing navigational calculations; ability to process and analyze navigation information; understanding the connection between theorems of spherical trigonometry and the formulas of calculations of the arc of a large circle; ability to use computer technology for automation of calculations; knowledge of the principle of location of the ship; understanding the causes of errors in navigation information and their types.

We present the example of the total hours distribution of the discipline complying with the curriculum of specialty 271 "River and sea transport". Consequently, three ECTS credits corresponding to 90 hours are provided for the study of the abovementioned discipline. Auditory hours: lectures - 20, practical classes -20 .

V. Table 2 below displays some tasks of a professional profile assured by different disciplines with indication of the corresponding blocks of "Higher Mathematics" course.

Thus, the programme of the "Higher Mathematic"'" course, in our opinion, will assure acquiring the professional (special) competencies (SC) (Ministry of Education and Science of Ukraine, 2018), namely: the ability to plan and navigate the voyage ( $\mathrm{SC} 2$ ); the ability to navigate in any conditions, applying appropriate methods, to obtain accurate positioning and optimally utilize all available navigational data for navigation (SC3); the ability to plan and provide safe loading, location, fixing, controlling during voyage as well as cargo unloading, including dangerous (SC11); knowledge and ability to control landing, stability and stress of the ship's hull, provide support for the vessel in the naval state (SC12); the ability to analyze and predict the processes and state of the navigation equipment in conditions of incomplete or limited information (SC 17).

The course programme will provide the following learning outcomes (results of study - RS):

1. Ability to maneuver and operate the ship in all conditions, determining the location by astronomical methods, as well as applying modern electronic radar equipment, paying particular attention to the knowledge of devices' working principles, limitations, sources of error and the ability to detect and correct improper displays and utilizing correction methods for obtaining a precise data of location; interconnection and optimal implication of all available navigational data for navigation (RS2).

2. Skills for assessing navigation information received from all sources, including radar, automated radar equipment and electronic navigationalinformation system complexes for decision-making purposes in order to avoid collision and control ship's safe navigation; navigation technique in conditions of the visibility absence (RS 4).

3. Knowledge and understanding of the impact of displacement tonnage, vessel's draught, trim, speed and the vessel's keel clearance reserve on maneuverability of the vessel; the influence of winds and current on navigation; sinking effect, shallow water impact, etc. (RP7).

4. Understanding the basic principles of ship structure, theory and factors affecting vessel's grounding and stability (RS 99).

The levels of students' acquired competencies may be different and determined by assesment. There is a wide range of methods for assessing students' learning outcomes(results of study): testing, performing calculations and graphic works, and passing exams. For example, in the National University "Odessa Maritime Academy" the planned forms of monitoring the "Higher Mathematics" learning results are: four calculations and graphic works (CGW) and two exams.

Table 3 lists the sections of the "Higher Mathematics" course for conducting CGW in semesters / courses.

Table 3

Parts of "Higher Mathematics" for Calculation and Graphic Works performance

\begin{tabular}{|c|c|c|}
\hline Types of individual tasks & Full-time study & Correspondence study \\
\hline CGW № 1. Linear algebra. Vector algebra. Elements of analytic geometry. & 1 semester & \multirow{2}{*}{1 year (course) } \\
\hline $\begin{array}{l}\text { CGW № 2. Differential calculus of functions of jne and many variables. } \\
\text { Integral calculus. }\end{array}$ & 1 semester & \\
\hline CGW № 3. Ordinary differential equations. Numerical and functional rows. & 2 semester & \multirow{2}{*}{2 year (course) } \\
\hline CGW № 4. Spherical trigonometry. Probability theory. & 2 semester & \\
\hline
\end{tabular}


Here we give an example of a Card for testing knowledge in "Fundamental Mathematics for navigation". These are questions covering topic "Mathematical analysis and navigation information processing":

1. The accuracy (error) implies.....

2. Classification of errors by sources ...

3. Systematic errors are ...

4. Random mistakes are ...

5. Failures are ...

6. The navigation parameter is determined as.... (give the definition)

7. A prior assessment is ...

8. A posteriori assesment is ...

9. Gauss' formula (write)

10. Bessel's formula (write)

11. The formula of the QME (quadratic mean error,) in terms of the measurement results (write).
Conclusions. It has been found out that mathematics has proven to be the fundamental discipline for further mastering of specialized (profile) disciplines. In the study mathematical competence is determined as a function of general and subject-specific competencies. It has been argued that the content of the study programmes of mathematical disciplines should be continuously monitored and assessed in order to determine whether the objective has been achieved or whether it is still relevant in the context of changes in the relevant subject areas. Tuning project's tools and approaches facilitate effective monitoring, evaluation, and improvement of the curriculum. Thus, the Tuning project provides a way for enhancing the quality of education at the level of curricula. We suggest the study of the defined issue to be the perspective task for further research.

\section{List of references}

Міністерство освіти і науки України, 2018. Про затвердження стандарту вищої освіти за спеціальністю 271 "Річковий та морський транспорт" для периого (бакалаврського) рівня вищої освіти. Наказ №1239 від 13.11.2018p. [online] Доступно: < https://mon.gov.ua/storage/app/media/vishcha-osvita/zatverdzeni\%20standarty/12/21/ 271-richkoviy-ta-morskiy-transport-bakalavr.pdf.> [Дата звернення 15 Квітень 2019].

Національний університет "Одеська морська академія", 2007. Профіль освітньо-професійної програми підготовки бакалавра "Судноводіння". [online] Доступно: <http://www.onma.edu.ua/wp-content/uploads/2016/11/Profilosvitnoyi-programy-bakalavra-SVF_2019.pdf $>$ [Дата звернення 9 Березень 2019].

Рашкевич, Ю.М. 2014. Болонський процес та нова парадигма вищої освіти: монографія. Львів: Львівська політехніка.

Стельмах, Я.Г. 2011. Формирование профессиональной математической компетентности студентов - будущих инженеров: автореферат. Кандидат наук. Самарский государственный технический университет.

Хуторской, А.В., 2005. Технология проектирования ключевых и предметных компетенций. Эйдос: Интернетжурнал, [online] Доступно: <http://www.eidos.ru/journal/2005/1212.htm.> [Дата звернення 8 Березень 2019].

Erasmus+UA, 2014. KA-1. Learning Mobility. [online] Available at: < https://erasmusplus.org.ua/en/erasmus/ka1learning-mobility.html $>$ [Accessed 8 April 2019].

Hochschule Flensburg University of Applied Sciences, 2000. Maritime transport, nautical and logistics. [online] Available at: <https://hs-flensburg.de/studium/bachelor/snl $>$ [Accessed 9 March 2019].

Jade-Hochschule, 1999. Nautical Science and Maritime Transport. [online] Available at: <https://www.jade-hs.de/en/ the-university/departments/maritime-and-logistics-studies/courses-of-study/nautical-science-and-maritime-transport/ > [Accessed 9 March 2019].

International Maritime Organization, 2014. Modal Course 7.03. [online] Available at: <http://library.bsma.edu.ge/ BOOKS/model_course7_03.pdf.> [Accessed 15 March 2019].

Lithuanian Higher Maritime School, 2008. Marine piloting. [online] Available at: $<\mathrm{http}: / / \mathrm{www} .1$ ajm.lt/lt/stojantiesiems/ stuiju-programos/juru-laivavedyba-2.html $>$ [Accessed 9 March 2019].

TUNING Educational Structures in Europe, 1999. Mathematics - Specific Competences. [online] Available at: < http:/ /www.unideusto.org/tuningeu/competences/specific/mathematics.html> [Accessed 12 April 2019].

\section{Translated \& Transliterated}

Ministerstvo osvity i nauky Ukrainy [Ministry of Education and Science of Ukraine], 2018. Pro zatverdzhennia standartu vyshchoi osvity za spetsialnistiu 271 "Richkovyi ta morskyi transport" dlia pershoho (bakalavrskoho) rivnia vyshchoi osvity. Nakaz № 1239 vid 13.11.2018. [About the approval of the standard of higher education in specialty 271 "River and sea transport" for the first (bachelor) level of higher education. Order № 1239 dated November 13, 2018$]$ [online]. Available at: < https://mon.gov.ua/storage/app/media/vishcha-osvita/zatverdzeni\%20standarty/12/21/271-richkoviy-tamorskiy-transport-bakalavr.pdf.> [access date: April, 15, 2019], [in Ukrainian].

Natsionalnyi universytet "Odeska morska akademiia" [National University "Odessa Maritime Academy"], 2007. Profil osvitno-profesiinoi prohramy pidhotovky bakalavra "Sudnovodinnia". [Profile of the educational and professional program of preparation of the Bachelor in Navigation]. [online]. Available: $<$ http://www.onma.edu.ua/wp-content/uploads/2016/ 11/Profil-osvitnoyi-programy-bakalavra-SVF_2019.pdf $>$ [access date: March 9, 2019], [in Ukrainian].

Rashkevych, Yu.M. 2014. Bolonskyi protses ta nova paradyhma vyshchoi osvity: monohrafiia [Bologna Process and New Paradigm of Higher Education: Monograph]. Lviv: Lviv Polytechnic, [in Ukrainian]. 
Stelmah, Ya.G. 2011. Formirovanie professionalnoy matematicheskoy kompetentnosti studentov - buduschih inzhenerov: avtoreferat [Formation of professional mathematical competence of students - future engineers: Abstract. $\mathrm{PhD}$ ]. Kandidat nauk. Samarskiy gosudarstvennyiy tehnicheskiy universitet, [in Ukrainian].

Hutorskoy, A.V., 2005. Tehnologiya proektirovaniya klyuchevyih i predmetnyih kompetentsiy. Eydos: Internet-zhurnal [Technology of designing key and subject competencies. Eidos: Online Magazine], [online]. Available at: <http:// www.eidos.ru/journal/2005/1212.htm.> [Accessed 8 March 2019], [in Russian].

Erasmus+UA, 2014. KA-1. Learning Mobility. [online] Available at: <https://erasmusplus.org.ua/en/erasmus/ka1learning-mobility.html $>$ [Accessed 8 April 2019], [in English].

Hochschule Flensburg University of Applied Sciences, 2000. Maritime transport, nautical and logistics. [online] Available at: <https://hs-flensburg.de/studium/bachelor/snl> [Accessed 9 March 2019], [in English].

Jade-Hochschule, 1999. Nautical Science and Maritime Transport. [online] Available at: <https://www.jade-hs.de/en/ the-university/departments/maritime-and-logistics-studies/courses-of-study/nautical-science-and-maritime-transport/> [Accessed 9 March 2019], [in English].

International Maritime Organization, 2014. Modal Course 7.03. [online] Available at: <http://library.bsma.edu.ge/ BOOKS/model_course7_03.pdf.> [Accessed 15 March, 2019], [in English].

Lithuanian Higher Maritime School, 2008. Marine piloting. [online] Available at: $<\mathrm{http}: / / w w w . l a j m .1 t / 1 t /$ stojantiesiems/ stuiju-programos/juru-laivavedyba-2.html> [Access date 9 March 2019], [in English].

TUNING Educational Structures in Europe, 1999. Mathematics - Specific Competences. [online] Available at: < http:/ /www.unideusto.org/tuningeu/competences/specific/mathematics.html> [Accessed 12 April 2019], [in English].

\section{Професійна спрямованість математичної підготовки бакалавра судноводіння}

\section{Олена Черкас ${ }^{1}$, Наталя Биковець², Марія Чумаченко ${ }^{3}$,}

1 кандидат фізико-математичних наук, доцент кафедри загальнонаукових дисциплін Дунайського інституту Національного університету "Одеська морська академія"

2 кандидат технічних наук, завідувач кафедри загальнонаукових дисциплін Дунайського інституту Національного університету "Одеська морська академія"

3 старший викладач кафедри загальнонаукових дисциплін Дунайського інституту Національного університету "Одеська морська академія"

Реферат. У статті розглядається питання математичної компетентності майбутнього бакалавра судноводіння. Математична компетентність представлена як функція загальних та предметно-спеціальних компетенцій. Показано, що математика є фундаментальною дисципліною для подальшого засвоєння профільних дисциплін. Компетентнісний підхід до математичної освіти розглядається як методологія, що базується на аналізі професійних вимог, котрі визначають пріоритетність компетенцій, необхідних для професійної діяльності бакалавра судноводіння.

У статті: сформульовані основні положення компетентністного підходу в термінах методології Tuning; перераховані загальні та предметно-спеціальні компетенції, що необхідні бакалавру судноводіння для успішної професійної роботи; проаналізовано структуру та зміст математичної підготовки майбутнього бакалавра судноводіння в окремих морських закладах вищої освіти України та Європи; у відповідності до стандартів IMO (International Maritime Organization, 2014) представлені вимоги щодо викладання математики в бакалаврів; розглянуто зв'язок між завданнями професійної орієнтації та відповідними блоками дисципліни "Вища математика"; аналіз сформульованих завдань, а також співпраця з викладачами профільних дисциплін дали змогу сформувати зміст курсу "Вища математика", приділити достатню увагу тим ії розділам, що необхідні для професійної освіти судноводія; наведено приклади видів контролю формування математичної компетентності; відображено місце математичної компетентності у переліку компетентностей, зазначених у профілі закладу вищої освіти; відображено роль математики в програмних результатах навчання.

Показано, що інструменти та підходи проекту Tuning дають змогу здійснити ефективний моніторинг, оцінку та вдосконалення навчальних програм для досягнення поставленої мети та внесення актуальних змін у відповідні предметні галузі.

Ключові слова: математична компетентність, бакалавр судноводіння, стандарти ІмО, програмні результати навчання, математика. 